\title{
O EMPREENDEDOR DE SI MESMO E A FLEXIBILIZAÇÃO NO MUNDO DO TRABALHO
}

\author{
Attila Magno e Silva Barbosa
}

\begin{abstract}
RESUMO
A existência social dos indivíduos, para muitos de seus intérpretes, pela via de discursos religiosos, de discursos políticos ou até mesmo pela via de algumas correntes do pensamento sociológico, parece não ser possivel sem a existência de metanarrativas que lhes confira sentido. Este artigo tem como objetivo fazer uma discussão teórica sobre a construção discursiva do empreendedor de si mesmo como o indivíduo apto a enfrentar as rápidas e drásticas mudanças ocorridas no mundo do trabalho com o advento da flexibilização produtiva. Advogamos em favor da hipótese de que essa construção discursiva não apresenta um tipo de indivíduo potencialmente acessível a todos, pois ele pressupõe a construção de si mesmo sem os suportes de um projeto comum de sociedade. Em outras palavras, estamos diante de um tipo de indivíduo desvinculado de pertenças coletivas e desprovido de qualquer tipo de proteção social fornecida pelo Estado e, por isso, inviável de ser pensado como padrão universal de comportamento em uma sociedade que busca a diminuição das desigualdades sociais.
\end{abstract}

PALAVRAS-CHAVE: produção flexível; precarização; insegurança social e ontológica; empreendedor de si mesmo.

\section{INTRODUÇÃO}

A existência social dos indivíduos, para muitos de seus intérpretes, pela via de discursos religiosos, de discursos políticos ou até mesmo pela via de algumas correntes do pensamento sociológico, parece não ser possível sem a existência de metanarrativas ${ }^{1}$ que lhes confira sentido. No primeiro caso, o fundamento dá-se por intermédio de determinadas situações transcendentes ao mundo material, já nos dois outros casos por intermédio de determinadas condições estruturais nas quais os indivíduos estão inseridos. Algumas metanarrativas conseguem manter sua vitalidade mesmo quando claramente se mostram incapazes de explicar de modo consistente e coerente a heterogeneidade de fatores que configuram as realidades sociais no atual estágio da modernidade.

\footnotetext{
1 No sentido que lhes é convencionalmente atribuído na Filosofia e na teoria da cultura, ou seja, de uma grande narrativa, uma narrativa de nível superior, capaz de explicar todo o conhecimento existente ou de representar uma verdade última sobre determinada realidade.
}

Isso ocorre devido ao fato de que, se por um lado os indivíduos têm sua autonomia ampliada em relação às suas filiações coletivas - dimensão constitutiva da modernidade -, por outro, ocorre um recrudescimento de um tipo de individualização, esta gerada pela perda de referências coletivas, a partir das quais se torna possível a construção de estáveis trajetórias de vida, profissional e/ou pessoal. Tal situação configurou-se como uma decorrência do colapso do compromisso fordista e da crise do Estado do Bem-Estar Social; desde então, deu-se ensejo àquilo que o sociólogo francês Robert Castel chama de processo de desfiliação.

Segundo Castel (2003), o processo de desfiliação corresponde ao tipo de exclusão social produzida pela crise do projeto da sociedade salarial. Em uma linha de raciocínio muito próxima a essa, Paugam (1999) propõe o termo desqualificação social para caracterizar esse movimento de expulsão gradativa de contingentes cada vez mais numerosos de indivíduos para fora do mercado de trabalho.

Como consequência, temos a configuração de novas imagens proletárias produzidas pelas transformações das relações salariais em tempos de 
produção flexível, imagens que contribuem sobremaneira para o enfraquecimento da capacidade de mobilização coletiva da classe trabalhadora devido à miríade de identidades sociais possíveis que o atual estágio da modernidade capitalista oportuniza.

Nos dias atuais, a heterogeneidade da classe trabalhadora assume contornos bem mais abissais do que assumiu no período fordista. A obviedade dessa situação manifesta-se na convivência do contrato de trabalho por tempo indeterminado e de diversas modalidades de contratos atípicos de trabalho, configurados pela lógica da flexibilização produtiva; isto é, todos aqueles contratos que não se inscrevem na tradicional condição de assalariamento fordista, como, por exemplo, os contratos de trabalho temporário, de tempo parcial, de terceirização (subcontratação) e de aprendizagem (estagiários). Além do trabalho informal, que nos países da periferia capitalista, como é o caso do Brasil, há muito se faz presente e só recentemente passou a ser um estorvo para os países do capitalismo avançado.

O fomento das estratégias de flexibilização no mundo do trabalho processa-se em estreita consonância com as estratégias políticas de inspiração neoliberal ${ }^{2}$, que vêem no encolhimento de algumas funções do Estado uma exigência para o bom funcionamento dos mercados. Estes são entendidos como esferas adequadas para garantir o vigor e a saúde socioeconômica em tempos de globalização. Para os defensores dessa lógica, como Friedrich Hayek, Milton Friedman e Peter Drucker, liberdade de mercado significa agir sem as amarras impostas por demandas sociais coletivas que possam impedir a livre expansão dos mercados. Não por acaso as empresas visarem o enfraquecimento de possíveis focos de resistência que possam emergir da configuração de um coletivo de trabalhadores coeso e cônscio diante das novas e sofisticadas formas de exploração do trabalho. Estratégias de individualização emergem atreladas à construção de um tipo de trabalhador polivalente que esteja sempre disposto a desen-

\footnotetext{
2 Aqui se entenda o conjunto de princípios ordenados para o ajuste estrutural do mercado, que consiste basicamente nas seguintes regras básicas: liberalização do mercado e do sistema financeiro, fixação dos preços pelo mercado, fim da inflação ("estabilidade macroeconômica") e privatizações (CHOMSKI, 2002).
}

volver as habilidades e obter as qualificações tidas como adequadas às mudanças de interesses do capital, principalmente, do capital financeiro.

Com isso em mente, pretendemos fazer uma discussão teórica a respeito da construção discursiva da imagem do empreendedor de si mesmo como indivíduo apto às rápidas mudanças que se processam no âmbito de um mundo do trabalho intensamente afetado pela lógica da flexibilização produtiva. Advogamos em favor da hipótese de que a noção de indivíduo veiculada nessa imagem não apresenta efetivamente uma figura paradigmática capaz de ser vislumbrada como dotada de capacidade efetiva de construir a si mesmo nos limites de um projeto comum de sociedade, porque a condição de precariedade, decorrente da fragilização do projeto da sociedade salarial, espraia-se por todos os cantos da vida em sociedade, enfraquecendo os vínculos sociais entre os indivíduos.

\section{O PROBLEMA DA PERDA OU NÃO DA CENTRALIDADE DO TRABALHO}

Na tradição legada por Marx (2008) o trabalho é entendido como o elemento central da condição humana, pois permite aos homens transformarem a natureza mediante ações planejadas, ao mesmo tempo em que estas transformam a natureza dos próprios homens. Nenhuma outra espécie animal é capaz de empreender tal feito, por mais bem elaborado que seja o resultado de seus esforços, vide o célebre exemplo das abelhas. O que nas outras espécies é uma ação resultante de impulsos instintivos, no homem é o resultado de uma ação previamente planejada, na qual o produto fazse presente em sua mente antes da intervenção sobre a matéria-prima sobre a qual incide. A reciprocidade transformadora, inerente ao trabalho, é o fator que o converte em um elemento central da sociabilidade humana. Até mesmo porque o trabalho é criador de valores de uso e, como trabalho útil, constitui-se em uma condição de existência do homem, independente de todas as formas de sociedade; uma eterna necessidade natural de mediação do metabolismo entre homem e natureza e, portanto, da vida humana. O trabalho na matriz do pensamento marxiano é a categoria central para o entendimento da condição humana por ser entendido como seu fator constitutivo.

Entretanto, desde os anos 1980, pensadores como Gorz (1987), Offe (1989) e Habermas (1990) têm advogado em favor da tese da perda 
da centralidade do trabalho como categoria fundamental à constituição da vida social. Alegam que a instabilidade na construção a partir da esfera do trabalho de um ambiente de vida social como uma unidade subjetiva estaria tornando-se cada vez mais inútil, em decorrência do tempo que os indivíduos a ela despendem. Ou seja, a identidade social e pessoal pela via do trabalho estaria perdendo força no atual contexto do capitalismo. Isso decorreria das inovações tecnológicas e do fato da biografia individual dos trabalhadores não necessariamente ter na formação profissional a realização de uma carreira a ela condizente. Para esses autores, a esfera do trabalho perde sua posição de categoria central na sociedade e cede lugar àquilo que Habermas denomina de "esfera comunicativa", em que as identidades constroem-se mais fortemente a partir do "mundo da vida", isto é, a partir de um conjunto de atividades que se realiza na interação intersubjetiva do dia-a-dia, não apenas na esfera institucional do trabalho.

Não temos dúvidas de que o trabalho, do ponto de vista de uma razão instrumental, constituise em elemento fundamental para a sobrevivência do modo de produção capitalista, pois ele é a fonte de valorização do capital, assim como ainda representa para um grande contingente de indivíduos espalhados pelo planeta um meio crucial de inscrição na vida social; principalmente quando consideramos que nos últimos dois séculos o modo de produção capitalista destituiu ou debilitou significativamente quaisquer outras formas de reprodução social da vida fora do espectro de influência de sua lógica instrumental.

Todavia, não podemos deixar de reconhecer que, com o advento da produção flexível e de suas inovações técnico-gerenciais, com a exemplaridade da fábrica enxuta, a fragmentação crescente da classe trabalhadora, advinda das transformações das relações salariais, com a fragilização do poder de pressão dos sindicatos e a desmobilização visível dos movimentos operários nos últimos trinta anos, fica cada vez mais difícil construir identidades sólidas pela via do trabalho. A situação de instabilidade que caracteriza as novas formas de emprego, surgidas no contexto da flexibilização produtiva e normatizadas sob a égide de políticas de inspiração neoliberal, torna as trajetórias profissionais bastante imprevisíveis. Principalmente se comparadas com as trajetórias profissionais possíveis nos países em que, no decorrer do sé- culo XX, o Estado do Bem-Estar Social incorporou direitos conquistados pela classe trabalhadora.

Segundo Castel (2003), as últimas três décadas testemunham a crise do projeto de sociedade salarial, isto é, aquele tipo de sociedade em que os indivíduos têm sua cidadania definida pela condição de trabalhador assalariado e o assalariamento é o eixo central da organização do corpo social. $\mathrm{Na}$ sociedade salarial o trabalho tornou-se uma exigência social devido à sua utilidade, daí justificar-se atrelar a ele não apenas um salário, mas todo um conjunto de proteções sociais. O assalariamento seria uma espécie de reconhecimento por parte da sociedade da utilidade social do trabalhador e, por isso, uma espécie de visto de entrada à sociedade na condição de consumidor.

Em um cenário social no qual a lógica da precarização dos direitos instala-se como um elemento constitutivo da nova configuração do mundo do trabalho, os trabalhadores vêem-se obrigados a aprender a lidar com as situações de risco decorrentes da condição de transitoriedade das novas formas de ocupação e do efeito desmobilizador que estas produzem sobre o coletivo dos trabalhadores. Transitar em um mundo de instabilidade e incertezas produzidas pela fragilização dos direitos vinculados à rede de proteção vinculada ao assalariamento é a característica fundamental da condição de trabalhador precarizado. Como indica Tiddi, este tipo de trabalhador encontra-se "[...] em uma fronteira entre a ocupação e não-ocupação e também em um não menos incerto reconhecimento jurídico diante das garantias sociais. Flexibilização, desregulação da relação de trabalho, ausência de direitos. Aqui a flexibilização não é riqueza. A flexibilização, por parte do contratante mais frágil, a força de trabalho é um fator de risco e a ausência de garantias aumenta essa debilidade. Nessa guerra de desgaste, a força de trabalho é deixada completamente descoberta, seja em relação ao próprio trabalho atual, para o qual não possui garantias, seja em relação ao futuro, seja em relação à renda, já que ninguém o assegura nos momentos de não-ocupação" (TIDDI, 2002, p. 75). Mesmo levando isso em conta, e considerando que as circunstâncias com as quais os trabalhadores precisam aprender a lidar em ambientes sociais nos quais a flexibilização e precarização 
do trabalho geram um processo de desfiliação, nós alinhamo-nos à tese de que, a despeito de todas essas dificuldades, para certos grupos sociais o trabalho ainda apresenta-se como uma referência dominante, pois, como advoga Castel, "é possível identificar vários círculos de identidade coletiva fundada, primeiro, na profissão (o coletivo de trabalho) e que pode prolongar-se em comunidade de moradia (o bairro popular), em comunidade de modo de vida (o bar, [...], o pertencimento sindical e político) [...]. Na sociedade industrial, sobretudo, para as classes populares o trabalho funciona como 'grande integrador', o que [...] não implica em condicionamento pelo trabalho (CASTEL, 2003, p. 531-532; sem grifos no original).

Aqui alinhamo-nos novamente com o autor, sobretudo no que diz respeito ao destacado na citação, pois estamos em total acordo com o fato de que, nesse tipo de sociedade, "o trabalho continua sendo uma referência não só economicamente, mas também psicologicamente, culturalmente e simbolicamente dominante, como provam as reações dos que não os têm" (idem, p. 578). Contudo, é necessário fazer uma ressalva, pois consideramos que tais reações manifestamse com maior intensidade nos países do capitalismo avançado em que o Estado do Bem-Estar Social fez-se presente, com ênfase maior à experiência francesa, que tem sido analisada por Castel a partir da emergência do que ele denomina "nova questão social", isto é, a situação decorrente do enfraquecimento da condição salarial e as suas consequentes formas de exclusão social.

Entretanto, não podemos, de modo algum, rejeitar súbita e desdenhosamente a idéia de que esteja ocorrendo um enfraquecimento da centralidade do trabalho como referência de construção identitária, como se tal enfraquecimento não estivesse de fato em andamento e não fosse empiricamente visível com a emergência de movimentos identitários claramente mais ligados às questões de gênero, de herança étnico-cultural, de sexualidade, de religiosidade, entre outras. Talvez devamos considerá-las como um sinal de que o trabalho, como atividade social, possa ter sido supervalorizado no que diz respeito à sua universalidade (como expressão da condição humana), assim como fonte primeva de referência identitária. Para nós, essa supervalorização deve-se ao fato de que o esquema analítico original do materialismo histórico está intimamente ligado à práxis revolucionária e ao papel de agente subjetivo-objetivo da superação do capital que é atribuído ao proletariado.

Em outras palavras, entendemos que o trabalho, como é entendido atualmente por nós, herdeiros do legado do projeto de modernidade, seja à luz da vertente liberal embebida ou não na ética protestante, seja à luz da exaltação do papel de sujeito histórico da classe proletária, tenha adquirido essa centralidade que lhe é atribuída tão somente nos limites do domínio do modo de produção capitalista, e não devido a uma universalidade que lhe seja inerente. Se tal impressão aflorou com tanto vigor e convicção nos últimos dois séculos, parece ter ocorrido muito mais por conta da vocação internacionalista do capitalismo e de sua expansão desestabilizadora de outras formas de reprodução social, do que de um protagonismo intrinsecamente universal que o trabalho possa efetivamente ter como expressão primeva da condição humana.

Para nós, persistir nesse entendimento é dar equivocadamente de barato que a razão instrumental manifesta na esfera das relações econômicas possui uma influência absoluta, que por sua vez sobrepõe-se às esferas da cultura e do mundo cotidiano, coisa que ela parece não mais fazê-lo. E teve-o porque o estágio anterior da modernidade não criou condições objetivas para o alargamento efetivo da autonomia dos indivíduos em relação às suas filiações coletivas.

Advogamos em favor da hipótese de que o problema tem sido o uso pervertido desse alargamento que é dado à narrativa do indivíduo como empreendedor de si mesmo em um cenário social de crescente pauperização e exclusão social produzidas pela fragilização do Estado como esfera pública garantidora dos direitos sociais constitutivos da condição salarial. O mau uso desse alargamento, um empreendimento da ofensiva neoliberal e da vocação volátil e descompromissada do capital financeiro em relação a qualquer tipo de demanda coletiva que represente um ônus indesejado aos mercados, cria um ambiente de incertezas e de insegurança social que nutre o recrudescimento de um novo tipo de individualização, em que os indivíduos passam a perceber-se como desvinculados de qualquer projeto coletivo comum, pois lhes é total ou parcial- 
mente negada a inserção social baseada no reconhecimento de direitos sociais incorporados àquilo que Castel (idem) chama de condição salarial.

Todavia, mesmo considerando o fato de o trabalho ter perdido parte de sua centralidade como fonte de identidade no mundo contemporâneo, principalmente nos países centrais do capitalismo, não podemos perder de vista o fato de que ainda é, até que sejam efetivamente apresentadas outras esferas constitutivas de existência social capazes de destituí-lo, o elemento dominante na vida de um enorme contingente de indivíduos, fundamentalmente daqueles que integram as classes populares. Isso porque, para esses indivíduos, a sobrevivência está diretamente ligada à necessidade de venderem sua força de trabalho e, por isso, apesar de eventualmente não perceberem subjetivamente a classe trabalhadora como sua principal fonte identitária, objetivamente a ela pertencem devido à sua condição. Veja-se que "quando a modernidade substituiu os estados prémodernos (que determinavam a identidade pelo nascimento e assim proporcionavam poucas oportunidades para que surgisse a questão do 'quem sou eu?') pelas classes, as identidades se tornaram tarefas que os indivíduos tinham de desempenhar. [...] Como Jean-Paul Sartre afirmou de modo admirável, para ser burguês não basta ter nascido na burguesia - é preciso viver a vida inteira como burguês! Quando se trata de pertencer a uma classe, é necessário provar pelos próprios atos, pela 'vida inteira' - não apenas exibindo ostensivamente uma certidão de nascimento -, que de fato se faz parte da classe a que se afirma pertencer. Deixando de fornecer essa prova convincente, pode-se perder a qualificação de classe, tornar-se déclassé" (BAUMAN, 2005, p. 55-56; grifos no original).

Como chama-nos atenção Bendassoli (2007), na perspectiva analítica defendida por Bauman, $o$ que estaríamos testemunhando no atual estágio da modernidade é a configuração de um contexto social em que o dinheiro tornou-se a principal força motivadora da ação, sendo que este não se apresenta apenas como fator que determina a tendência atual de avaliar o valor e a dignidade humana a partir de recompensas monetárias, mas também, e principalmente, é o elemento responsável pelo deslocamento da subjetividade dos indivíduos para a esfera do consumo. A conseqüência desse processo seria um golpe destituidor da ética do tra- balho e da sua visão valorizadora do trabalho e do indivíduo que trabalha.

Para Bauman (1998), estamos testemunhando o deslocamento da subjetividade da esfera do trabalho para a esfera do consumo, ou seja, a passagem de uma sociedade de produtores para uma sociedade de consumidores. Se na primeira os indivíduos são integrados basicamente por sua capacidade de produzir, na segunda seria a imagem dos indivíduos como consumidores que assume primazia. Se na primeira tínhamos a ética tradicional do trabalho que limitava ferreamente a liberdade individual, na segunda a liberdade converteu-se em imperativo categórico.

O ponto fundamental de mudança dessa passagem diz respeito ao deslocamento dos referenciais de construção da identidade da esfera do trabalho para a esfera do consumo. Na sociedade de consumidores, a identidade, similarmente ao que ocorre com qualquer bem de consumo, passou a ser adquirida nos moldes estabelecidos por um processo que pressupõe aquisição, descarte e apropriações contínuas. A construção da identidade em um tipo de sociedade passa a nortear-se pelos caminhos voláteis e erráticos do mercado, por esse motivo ela converte-se em um processo de conquista. Esse processo teria como suas forças motrizes os fluxos de imagens e a busca de sensações (idem; BENDASSOLI, 2007).

Ao consideramos o processo de individualização inerente ao projeto da modernidade, mas especificamente a sua promessa de autonomização, não podemos simplesmente enxergá-lo em sua dimensão negativa, até mesmo porque não temos dúvidas de que exista uma dimensão potencialmente positiva, principalmente quando consideramos que o mundo hoje está cada vez mais interconectado pelas tecnologias informacionais e de transportes.

Transitar pelo planeta tornou-se não apenas mais fácil, mas também uma experiência de menor estranhamento. Isso se deve ao caráter "cosmopolita" da chamada "cultura global" que se propaga pelos fluxos informacionais midiáticos e corporifica-se em um amálgama confuso e incoerente que a indústria cultural trata de fomentar sem preocupar-se em esmiuçar adequadamente os sentidos originais que os diferentes elementos que o constituem de fato possuem. Entretanto, não podemos esquecer que o acesso a esse 
"cosmopolitismo" é absolutamente seletivo e está normalmente circunscrito àqueles que constituem a nova elite global, ou seja, o conjunto de indivíduos beneficiados pela mobilidade que seus capitais econômico, cultural e social conferem-lhes no mundo globalizado e que, conseqüentemente, podem efetivamente desenraizarem-se de seus lugares de origem (BAUMAN, 2003).

No caso da forma de individualização inspirada no ideário neoliberal e da lógica da flexibilização é inegável a existência de certa carga negativa e de efeitos prejudiciais para as formas de sociabilidade dos indivíduos, principalmente quando consideramos o fenômeno da precarização dos direitos vinculados à condição de assalariamento e a fragilização dos vínculos sociais produzida pela crise do Estado como esfera provedora de bens públicos. Como indica Paugam, é preciso considerar que "a experiência da precariedade profissional é, efetivamente, mais dolorosa quando atinge os indivíduos no cerne da vida ativa. Quanto maior é a precariedade profissional, menor é a possibilidade do indivíduo auferir ajuda do seu meio social [...] a consequência disto tudo é que o risco de enfraquecimento dos vínculos sociais é proporcional às dificuldades encontradas no mercado de trabalho" (PAUGAM, 1999, p. 72).

Essa situação incide com toda intensidade sobre o conjunto de indivíduos massificados pela impossibilidade de integração social em um projeto comum de sociedade que os reconheça como dotados de direitos sociais. O mal-estar gerado pela insustentabilidade fática desse tipo de individualização, em termos duradouros nas trajetórias de vida pessoal da maioria, conduz os indivíduos a apegarem-se a qualquer metanarrativa ou ideologia que lhes dê a mínima sensação de segurança ontológica, e aqui estamos falando de qualquer tipo, religiosas, políticas ou as ditas "científicas". Por motivos como esses, entendemos ser fundamental, caso queiramos efetivamente compreender bem as mudanças ocorridas no mundo do trabalho, levar em conta a sugestão de Nardi, quando ele defende que "[...] as relações entre o sujeito e o trabalho devem ser analisadas buscando identificar os dispositivos que atuam nos processos de subjetivação, para, desta forma, compreender os parâmetros que balizam a reflexão ética dos trabalhadores em relação à vida em sociedade, ou seja, à decodificação das regras morais presentes no jogo das verdades próprio a cada época. Estes dispositivos compreendem sanções sociais que agenciam modos de ser. Dependem, portanto, das relações de poder presentes nos jogos de dominação e resistência que inscrevem os indivíduos na vida em sociedade" (NARDI, 2006, p. 52).

\section{INSEGURANÇA SOCIAL E ONTOLÓGICA EM TEMPOS DE FLEXIBILIZAÇÃO PRO- DUTIVA}

Nos modelos de produção flexível, a fábrica enxuta é o ideal a ser alcançado; ideal este que se busca alcançar por intermédio da remoção das camadas consideradas desnecessárias de trabalho vivo. Sobre esse assunto, Taiichi Ohno, engenheiro responsável pela criação do modelo de produção japonês da Toyota, é bastante claro: "na Toyota, o conceito de economia é indissociável da busca de redução de efetivos e de redução de custos" (Ohno apud CORIAT, 1994, p. 33). Para Ohno, basicamente há duas maneiras de pensar a produtividade: a) aumentar as quantidades produzidas e b) reduzir o pessoal de produção. No seu entendimento, a primeira maneira não só era a mais popular no período taylorista-fordista, como também era a mais fácil, porque a segunda implica a necessidade de repensar-se todas as variáveis e detalhes da organização do trabalho.

Para Coriat (1994), o modelo Toyota inverte as regras tradicionais da lógica fordista, que se assentavam na parcelização das tarefas e separação entre concepção e execução, em que os trabalhadores do chão de fábrica eram desincumbidos de pensar o processo de trabalho ao qual tinham de sujeitar-se. Tal mudança teria sido possível devido ao estabelecimento paralelo do desenrolar dos fluxos reais de produção e de um fluxo de informação que vai de jusante à montante da cadeia produtiva, o que torna a produção mais enxuta, pois assim ela ocorre no ritmo dos pedidos realizados. Desta feita, esse sistema, denominado just in time, não preconiza a produção em larga escala, mas sim em lotes de séries menores determinados pelo fluxo da demanda. A partir do final da década de 1960, com um maior desenvolvimento da telemática e da robótica, diminui-se ainda mais a necessidade de trabalho vivo e, conseqüentemente, o processo de trabalho passou a ser pensado e realizado em equipes de trabalhadores mais diretamente ligados ao processo produtivo. A partir de então, o modelo japonês de produção começa a posicionar-se como um exemplo a ser observado e considerado como uma solução pos- 
sível para as crises posteriores a 1973 do modelo de acumulação capitalista baseado na produção taylorista-fordista vigente no Ocidente. Não apenas o sistema just in time, mas o sistema Total Quality $\mathrm{Control}^{3}$, a noção de team work, as práticas de outsourcing (terceirização), $\mathrm{Kan}-\mathrm{Ban}^{4}, 5 \mathrm{~S}^{5}$, entre outras que integram o rol dos modelos de produção flexível passaram a ser copiadas e adaptadas às realidades dos países capitalistas ocidentais.

No modelo toyotista, o conceito de flexibilidade não se restringe simplesmente a uma condição de flexibilidade interna proveniente da maior capacidade de adaptação dos trabalhadores ante um processo de ampliação do conteúdo e da variação das tarefas a serem executadas, ele também pressupõe uma flexibilidade externa, decorrente da

3 Sistema administrativo organizado pelo Grupo de Pesquisa de Controle de Qualidade da JUSE (Union of Japanese Scientists and Engineers) com base em diversas idéias e práticas gerenciais norte-americanas, entre as quais: aspectos da organização do trabalho, de Frederick W. Taylor (1856-1915); o controle estatístico de qualidade desenvolvido por Walter A. Shewhart (1891-1967); os conceitos de Abraham Maslow (1908-1970) sobre o comportamento humano; as ideias sobre qualidade contidos nos trabalhos de William E. Deming (1900-1993) e de Joseph M. Juran (1904-2008). É um sistema concebido para garantir a sobrevivência da empresa por meio de uma mudança substancial nas práticas gerenciais. A expressão "Total Quality Control" deve ser creditada a Armand V. Feigenbaum, especialista norte-americano em controle de qualidade, aparecendo em seu livro "Total Quality Control”, publicado em 1961. Na concepção de Feigenbaum, o controle da qualidade é exercido por especialistas, o que o mantém inscrito no modelo taylorista-fordista. O modelo japonês difere desse enfoque porque adota o Controle da Qualidade Total com envolvimento de todos os empregados de todos os setores da organização, em todos os níveis hierárquicos. Daí ser denominado de TQC "no estilo japonês".

4 Sistema desenvolvido por Taiichi Ohno que consiste de um cartão elaborado para evitar o excesso de produção e garantir que as peças necessárias sejam passadas de um processo a outro na ordem inversa. É um sistema de reabastecimento projetado para controlar as quantidades de produção em cada processo.

5 Método de organização do espaço de trabalho. O objetivo primordial desse método é evitar a perda de tempo na procura de objetos e ferramentas usadas no espaço compartilhado de trabalho. Os 5S são: Seiri: senso de utilização; Seiton: senso de organização; Seiso: senso de limpeza; Seiketsu: senso de padronização; Shitsuke: senso de autodisciplina estratégia de redução de custos com efetivos por intermédio do estabelecimento de uma rede de subcontratações de empresas fornecedoras de mão-de-obra para as atividades consideradas não diretamente ligadas à atividade-fim. Nessa matriz produtiva, "o conceito de flexibilidade do trabalho abrange quatro dimensões: emprego, conteúdo do trabalho, jornada de trabalho e remuneração" (NEVES, 2006, p. 151). Todas essas dimensões contribuem significativamente para o estabelecimento de um tipo de gestão e organização do trabalho que conduz à individualização do trabalhador.

A fábrica pensada por Ohno é organizada para trabalhar com um número mínimo de operários, objetivando torná-los os mais multifuncionais quanto possível, isto é, visando uma maior flexibilidade do trabalho. Não por outra razão, faz-se necessário apelar para a subjetividade do trabalhador. No toyotismo, fábrica eficiente é sinônimo de fábrica mínima, de fábrica que, com um número menor de trabalhadores, consegue-se aumentar os níveis de produtividade. Situação bem diferente do modelo tayloristo-fordista, em que, como salienta Antunes (1999), a pujança de uma empresa era mensurada pelo número de operários que nela exerciam suas atividades de trabalho. Por isso, não é à toa que a experiência japonesa da Toyota tem na terceirização uma prática inerente ao seu modelo organizacional de fábrica enxuta.

Atualmente, a fábrica mínima, ou se preferirmos, a "fábrica enxuta", passa a ser entendida como condição básica de sobrevivência empresarial devido à saturação progressiva da norma de consumo fordista que deu origem a uma demanda de consumo por bens duráveis e, ao mesmo tempo, flutuante e diversificada. Como consequência, mercados mais incertos e heterogêneos surgiram e produziram uma contradição direta com a rigidez e a onerosidade do modelo de produção tayloristo-fordista, que só consegue amortizar rapidamente os investimentos em equipamentos com uma produção contínua em massa. Portanto, o aumento da variabilidade da demanda exigiu uma maior flexibilidade do processo de trabalho via introdução de meios de trabalho aptos para o ajuste da capacidade produtiva ao volume e à composição desse tipo de demanda (BIHR, 1998). Assim, a fábrica enxuta passou a ser apresentada como a solução para a crise do paradigma tayloristo-fordista e, a partir de então, tudo aquilo que é visto pelas empresas como ex- 
cesso dentro do processo produtivo e exceda a capacidade de absorção do mercado precisa ser eliminado, tendo em vista a necessidade das empresas tornarem-se mais competitivas no mercado global.

O atual padrão de acumulação capitalista, isto é, o regime de acumulação flexível, tem nos avanços da tecnologia da informação um suporte fundamental para a disseminação e a legitimação da lógica societal que lhe é inerente, por conta disso, não é por acaso estarmos testemunhando no mundo contemporâneo uma transformação dramática do conceito de ocupação. Isto é, a formação de um novo paradigma de trabalho, no qual os motes são a flexibilização, a precarização e o desprovimento das garantias de estabilidades associadas ao padrão tradicional de emprego. A perplexidade causada por essa situação nas sociedades ocidentais, se é nitidamente mais dramática, o é porque nestas o emprego tem desempenhado um papel central não apenas no que diz respeito à obtenção de renda, mas também como um elemento que possibilita a integração social do indivíduo e a formação de sua identidade pessoal (DUPAS, 1999).

O que estamos testemunhando é o surgimento de uma condição de vulnerabilidade tanto nas condições objetivas de vida dos trabalhadores, quanto na percepção subjetiva que estes fazem de si mesmos a partir da esfera do trabalho. Nesse sentido, a sociedade passa a conviver com a fragilidade da relação salarial, mas também a assistir o desmoronamento dos princípios reguladores e fundadores de coesão do sistema de vida social e o ambiente de insegurança social dele decorrente (CASTEL, 2003). Essa situação configura uma sensação de insegurança ontológica para todos aqueles que por ela são afetados, e aqui entendamola como a falta de sentido de continuidade e ordem nos eventos que estão dentro ou não do ambiente perceptual imediato dos indivíduos (GIDDENS, 2002). Até mesmo porque "a insegurança social não alimenta somente a pobreza. Ela age como um princípio de desmoralização, de dissociação social à maneira de um vírus que impregna a vida cotidiana. Dissolve os laços sociais e mina as estruturas psíquicas dos indivíduos. Ela induz uma 'corrosão do caráter' para retomar uma expressão que Richard Sennett emprega num outro contexto. Estar em numa insegurança permanente é não poder nem controlar o presente, nem antecipar positivamente o futuro" (CASTEL, 2005, p. 31).

Essa situação passou a tornar-se visível a partir do final da década de 1970, pois um processo de fragmentação crescente do proletariado ocidental, decorrente da lógica da flexibilização produtiva, deu início a um movimento de desomogeinização e paralisação deste como força social, não apenas no que concerne ao potencial de sujeito coletivo histórico de derrubada do poder do capital que lhe fora atribuído no legado teórico marxista, mas também nos limites da atuação econômico-corporativa que caracterizava a atuação dos sindicatos no âmbito do período de vigência do "compromisso fordista". Desse modo, a força de trabalho que caracterizou o período fordista foi atingida severamente pelas mudanças ocorridas nas relações de emprego e trabalho promovidas pelos processos de inovações técnico-gerenciais promovidos pela flexibilização produtiva.

Também é preciso não perder de vista que a flexibilização não se restringiu aos limites meramente internos das fábricas, já que, como parte de seus pressupostos, também se fez necessário repensar as relações salariais existentes; o que acabou por configurar uma situação na qual a flexibilização dos direitos trabalhistas passou a ser apresentada como um processo de ajustamento às novas formas de ralação entre capital e trabalho que surgiram com o modelo de produção flexível. Ante essas mudanças, tanto a homogeneidade das categorias profissionais, quanto (mais amplamente) as instâncias de regulação coletivas passaram a ser colocadas em cheque. A ocorrência disso, como bem demonstra Castel, está intimamente ligada ao fato de que "o desemprego em massa e a precarização das relações de trabalho não afetam apenas diferencialmente as diversas categoriais de trabalhadores ferindo mais duramente a base da hierarquia salarial. Provocam também imensas disparidades intracategoriais - por exemplo entre dois operários, mas também entre dois quadros do mesmo nível de qualificação, um dos quais terá garantido seu emprego. A solidariedade dos estatutos profissionais tende assim a transformar-se em concorrência entre iguais. Em vez de unir todos os membros de uma mesma categoria em torno de objetivos comuns que beneficiarão o conjunto do grupo, cada um é levado a colocar em evidência sua diferença para manter ou melhorar sua própria condição" (idem, p. 44-45; grifos no original). 
A transformação da relação salarial aliada às estratégias de cooptação dos trabalhadores aos interesses das empresas por intermédio da estratégia de individualização do trabalhador é fator decisivo para a crescente heterogeneização e desmobilização da classe trabalhadora na era da produção flexível. O modelo de fábrica enxuta, pensada por Ohno, é a corporificação dessa situação desassociativa, pois instaura de um lado um núcleo cada vez mais reduzido de trabalhadores protegidos pelo welfare rareado oportunizado por grandes empresas e, de outro, um conjunto de trabalhadores cada vez mais numeroso desprovido de quaisquer benefícios sociais realmente efetivos, segregando-os não apenas pela diferenciação de estatutos, mas também por recortes de qualificação técnica, de gênero e geracionais. Por isso, "quando se fala hoje da reestruturação do mundo do trabalho e da preponderância que é preciso atribuir ao bom desempenho das empresas para serem competitivas em face dos desafios impostos pela concorrência exacerbada e pela globalização do intercâmbio, não é mais a mesma dinâmica das relações profissionais que se invoca como sendo a mais apta a assegurar o desenvolvimento econômico. É muito mais do contrário que se trata. Uma gestão fluída e individualizada do mundo do trabalho deve substituir sua gestão coletiva à base de situações estáveis de emprego. Com um pouco de recuo começa-se a perceber que o que está em jogo, através da mutação do capitalismo que começou a produzir seus efeitos no começo dos anos de 1970, é fundamentalmente a instauração de uma mobilidade generalizada das relações de trabalho, das carreiras profissionais e das proteções ligadas ao estatuto do emprego. Dinâmica profunda que é, simultaneamente, de descoletivização, de reindividualização e de insegurização" (idem, p. 45; grifos no original).

O quadro produzido pela transformação das relações salariais tem dado ensejo à configuração de novas imagens proletárias, sendo que três grandes conjuntos estão delineando-se: a) os proletários estáveis com garantias, uma reminiscência do período tayloristo-fordista; b) os proletários excluídos do trabalho, aqueles condenados ao desemprego e à dependência da seguridade social; c) uma massa flutuante de trabalhadores instáveis, na qual se incluem os trabalhadores em tempo parcial, os temporários, os informais e os terceirizados. Essas diferentes imagens dificultam a construção de uma identidade comum da classe trabalhadora, assim como também contribuem para o enfraquecimento dos sindicatos como agentes coletivos de defesa dos interesses dos trabalhadores (BIHR,1998).

Do ponto de vista do capital, é correto pensar que a mudança de um modelo de produção mais rígido para um mais flexível traz mais benefícios do que malefícios. Até porque, além da redução de custos operacionais decorrentes da substituição de trabalho vivo por trabalho morto, ou seja, da substituição de força de trabalho por inovações tecnológicas possibilitadas pelas aplicações da telemática e da robótica no universo empresarial, parece-nos claras outras três situações benéficas geradas pela associação dessas aplicações ao conjunto de técnicas organizacionais inspiradas no modelo japonês, quais sejam: 1) a apropriação não apenas da força física do trabalhador, mas também de sua capacidade intelectual devido à exigência por um maior engajamento na gestão dos processos produtivos nos quais estão diretamente envolvidos (vide a criação dos círculos de controle de qualidade); 2) o estabelecimento de um ambiente competitivo interno entre os trabalhadores diretos entre si e destes com os terceirizados, pois o emprego passa a ter de ser garantido por demonstrações contínuas não apenas de competência e envolvimento com o trabalho, mas também de adesão aos ideários da cultura organizacional das empresas; 3 ) o enfraquecimento da coesão e da solidariedade entre os grupos com diferentes estatutos que integram a classe trabalhadora, vide o enfraquecimento do poder de pressão dos sindicatos sobre as empresas e o esvaziamento do Estado como esfera promotora de acesso aos direitos políticos e sociais.

No período tayloristo-fordista, apesar das heterogeneidades e desigualdades existentes entre os membros da classe trabalhadora, era possível notar a predominância de certa tendência à homogeneização devido a uma "estratégia de integração" do proletariado possibilitada pelo convívio de grandes contingentes de operários com o mesmo estatuto social nas instalações fabris, o que de certa maneira permitia-lhes uma troca de experiências que permitia mais facilmente pensar a idéia de um destino comum e, conseqüentemente, de uma identidade comum que tornava menos difícil a tomada de uma "consciência de classe" em oposição aos proprietários dos meios de produção. Essa tendência foi fortalecida após o tér- 
mino da II Guerra Mundial, devido à preocupação de que os países centrais do capitalismo passaram a ter com uma possível expansão da influência da experiência socialista soviética sobre o imaginário dos trabalhadores no que concerne à possibilidade de um modelo societal alternativo ao capitalismo. A partir de então, configurou-se a necessidade de instituírem-se os "direitos sociais" ligados ao trabalho por intermédio dos mecanismos compensatórios do Welfare State, que traziam consigo uma forte estratégia de inserção, mínima que o fosse, da classe trabalhadora nos padrões de consumo do modelo fordista visando o enfraquecimento do potencial de sujeito histórico revolucionário do proletariado.

Nesse contexto, os sindicatos passaram a ser reconhecidos pelo Estado como entidades representativas dos interesses econômico-corporativos das categoriais de trabalhadores a que representavam, e não como portadores de um projeto de classe alternativo ao capital. O resultado disso foi um "compromisso social" entre capital e trabalho viabilizado primordialmente nos países do capitalismo avançado, em que a demanda acompanhava os investimentos em larga escala (HARVEY, 2004; CASTEL, 2005).

As principais características desse compromisso foram a negociação coletiva, a uniformização da condição jurídica dos diferentes trabalhadores e a efetividade do emprego. Essa estratégia de disponibilização de garantias de direitos sociais e políticos, mínimos que o fossem aos olhos dos sindicatos e partidos de esquerda que a ela não aderiram, como se sabe, foi bastante exitosa, pois se por um lado promovera melhorias efetivas nas condições de vida dos trabalhadores dos países do capitalismo avançado posteriormente a 1945 , por outro contribuiu de modo significativo para a integração dos trabalhadores ao modo de vida capitalista, já que os mesmos passaram a ter sua atuação social circunscrita às demandas econômico-corporativas de suas categorias profissionais nos limites do próprio compromisso que fora estabelecido, configurando assim uma espécie de "parceria antagônica" entre capital e trabalho. Dessa feita, a tendência homogeneizante da classe trabalhadora pela via das categorias profissionais ganhou corpo, pois, o "“compromisso social' que caracteriza os anos de crescimento é um equilíbrio mais ou menos estável, negociado por ramo e por profissão, fruto de acordos interprofissionais entre sindicatos e patronato, sob a égide do Estado. Havia como que um círculo virtuoso entre as relações de trabalho estruturadas num modo coletivo, a força de sindicatos de massa, a homogeneidade das regulações do Direito do Trabalho e a forma generalista das intervenções do Estado que permite uma gestão coletiva da conflitualidade social" (idem, p. 44).

Apesar de todas as tensões sociais geradas no âmbito do compromisso fordista, principalmente aquelas relacionadas ao problema da rotinização e ao esvaziamento do conteúdo subjetivo do trabalho, fatores que motivavam as ações sindicais na busca por melhorias das condições de trabalho, tanto nos países em que efetivamente fez-se presente, como por exemplo, o Canadá e parte da Europa Ocidental, quanto naqueles em que se deu de modo parcial ou restrito, como o Brasil, o fordismo conseguiu manter-se firme até a crise de 1973. Vide os padrões materiais de vida e altos lucros corporativos alcançados nos países do capitalismo avançado (HARVEY, 2004).

Diferentemente do quadro configurado pelo compromisso fordista, no qual era possível para os trabalhadores por ele beneficiados pensarem suas trajetórias de vida em longo prazo, em um contexto social norteado pelo ideário neoliberal e baseado na lógica do regime de acumulação flexível, a noção de longo prazo fica bastante fragilizada devido à fluidez e à instabilidade das relações sociais. Para Ehrenberg (1991) a indeterminação apresenta-se como uma tendência norteadora da vida em sociedade, principalmente nas sociedades democráticas avançadas. Isso porque, como lembra Bendassoli (2007), a incerteza em relação ao futuro e a fragilização da confiança em um tipo de sociedade que seja capaz de responsabilizar-se pelas ações dos indivíduos e por projetos e ideais publicamente sustentados são expressões claras dessa tendência norteadora. No período no qual se tinha à vista o projeto do Estado do Bem-Estar Social, "a vida era vivida pela maior parte das pessoas como um destino coletivo; hoje, ela é uma história pessoal. Cada um, de agora em diante, indubitavelmente confrontado com o incerto, precisa apoiar-se sobre si mesmo para inventar sua própria vida, lhe conferir sentido e engajar-se ativamente" (EHRENBERG, 1999, p. 18).

Segundo Ehrenberg, a receita que é hoje apresentada ao indivíduo para lidar com as incertezas acarretadas por essa situação é o "culto à 
performance". Em uma mistura discursiva que abarca o discurso esportivo, do consumo e, principalmente, empresarial, tem-se um recrudescimento do individualismo sobre uma nova base: símbolo da valorização das iniciativas da sociedade civil e da crise da representação política baseada em corporações coletivas.

$\mathrm{Na}$ impossibilidade da esfera política lidar adequadamente com os problemas causados pela crise do projeto do Estado do Bem Estar Social entenda-se aqui principalmente nos países da Europa Ocidental -, o econômico chama para si a competência de dizer como fazê-lo, daí, a empresa ter sido apresentada como a solução miraculosa, posto que se torne cidadã, vide o espraiamento do discurso da responsabilidade social no meio empresarial, inclusive no Brasil, como indicam Paoli (2002) e Barbosa (2007). Bendassoli sustenta, seguindo a linha interpretativa proposta por Ehrenberg: "Nesse ambiente, altera-se a representação social da empresa, a qual deixa de ser percebida como instrumento de dominação dos grandes sobre os pequenos para funcionar como modelo ideal de conduta para o indivíduo, já que ela é símbolo de eficácia e de iniciativas ousadas num contexto turbulento. Ela abandona o terreno econômico stricto sensu e fornece modelos de subjetivação para a grande massa da população. A empresa é a fornecedora oficial de um tipo muito particular de singularização: a performance" (EHRENBERG, 2007, p. 207).

Desse modo, não é de admirar-se que a figura do empreendedor de si mesmo esteja embebida na idéia de responsabilização dos trabalhadores; não apenas no que concerne ao processo produtivo e ao processo de trabalho, mas também a uma eventual condição de desemprego que possa vir sobre eles nos próximos programas de reestruturação produtiva. Afinal de contas, como cada indivíduo situa-se em um mercado de trabalho cada vez mais competitivo, é entendido nessa matriz discursiva como uma situação que depende fundamentalmente do desempenho de cada um, isto é, da performance.

Nos últimos trinta anos, os discursos de inspiração neoliberal e as estratégias de flexibilização produtiva procuraram disseminar a idéia de que o agravamento do desemprego, o aumento do mercado informal de trabalho e a intensificação dos problemas sociais são consequências da incapacidade do Estado em li- dar adequadamente com essas questões, haja vista que o Estado teria se concentrado em atividades que seriam mais bem conduzidas pelos mercados. A omissão do fato de que o desemprego estrutural e a instalação da precarização do trabalho são inerentes ao modelo de acumulação flexível, aliada à desmobilização dos sindicatos como agentes coletivos de representação da classe trabalhadora produzida pelo paradigma produtivo das fábricas enxutas, são fatores-chaves para a disseminação de duas idéias centrais dessa lógica: a) o mercado como sendo mais eficiente que o Estado no que diz respeito à administração dos fluxos econômico-financeiros em tempos de globalização; b) a responsabilização dos indivíduos por sua condição de empregabilidade e pela permanência ou não em determinada condição de existência material.

Ambas idéias podem ser entendidas como partes constitutivas de uma mesma construção discursiva que tenta impor-se como o antídoto adequado ao ambiente de insegurança social que os processos de flexibilização instalam tanto no mundo do trabalho quanto no que se refere à redefinição do papel do Estado como esfera pública de garantias de direitos sociais e de acesso aos bens públicos. No cerne dessa construção discursiva está o projeto de um novo indivíduo, polivalente, desvinculado de filiações coletivas, um indivíduo resiliente que se perceba como o único responsável por sua condição material de existência; o que em termos do mundo do trabalho significa dizer um indivíduo responsável por sua condição de empregabilidade, um indivíduo que esteja disposto a aderir aos objetivos da empresa que lhe emprega pelo tempo que esta estiver disposta a lhe empregar.

\section{A REFLEXIVIDADE NO MUNDO DO TRA- BALHO EM TEMPOS DE GLOBALIZAÇÃO}

A atual configuração do capitalismo no contexto da globalização estabelece a organização da economia em torno de um padrão de organização em redes globais, nas quais a interconexão e interdependência dos fluxos de capital, de tecnologia, de interação organizacional, de informações, de imagens, sons e símbolos apresentam-se como a principal característica. Sendo que tais fluxos, segundo Castells, "não representam apenas um elemento da organização social: são a expressão dos processos que dominam nossa vida econômica, política e simbólica" (CASTELLS, 
2002, p. 501). Seguindo essa linha de raciocínio, Castells entende que no mundo atual ocorre "[...] uma nova forma espacial característica das práticas sociais que dominam e moldam a sociedade em rede: o espaço de fluxos. $O$ espaço de fluxos é a organização material das práticas sociais de tempo compartilhado que funcionam por meio de fluxos. Por fluxos, entendo as sequências intencionais, repetitivas e programáveis de intercâmbio e interação entre posições fisicamente desarticuladas, mantidas por atores sociais nas estruturas econômica, política e simbólica da sociedade. Práticas sociais dominantes são aquelas que estão embutidas nas estruturas sociais dominantes. Por estruturas sociais dominantes, entendo aqueles procedimentos organizacionais e instituições cuja lógica interna desempenha papel estratégico na formulação das práticas sociais e da consciência social para a sociedade geral" (CASTELLS, 2002, p. 501; sem grifos no original).

No atual estágio de internacionalização do capitalismo, as empresas com orientação para o mercado cada vez mais norteiam suas ações sob a égide do isomorfismo institucional que caracteriza o campo organizacional no qual elas estão inseridas (DIMAGGIO \& POWELL, 1999). Desse modo, está claro que o modelo organizacional da empresa em rede, que se tornou hegemônico em tempos de acumulação flexível, só é viável devido ao caráter isomórfico das práticas técnico-gerenciais adotadas dentro dos campos organizacionais.

O atual estágio de desenvolvimento do capitalismo tornou definitivamente insuficiente os meros limites do Estado-nação para os interesses da acumulação capitalista, assim, como indica Nardi, "a reestruturação produtiva pode ser definida como a transformação do modelo de acumulação taylorista-fordista no contexto do estado-nação para a acumulação flexível no contexto da globalização" (NARDI, 2006, p. 53).

A disseminação de sistemas organizacionais padronizados permite que o fluxo informacional transite pela rede empresarial a partir de parâmetros organizacionais constituídos sobre a égide da racionalidade instrumental do mercado. Parâmetros estes que estabelecem os critérios globais de avaliação de desempenho empresarial para todo um conjunto de interessados, ou seja, (primordialmente) os acionistas.
Contudo, é preciso que se diga que outros atores sociais envolvidos, como os trabalhadores e as comunidades, nas quais as atividades da empresa atuam, também são afetados pelos efeitos dessa padronização. Dizemos isso porque todos os sistemas e práticas organizacionais inspirados nos preceitos da flexibilização produtiva, como just in time, círculos de controle de qualidade, a noção de team work, as práticas de outsourcing (terceirização), Kan-Ban e 5S promovem mudanças na vida social de todos aqueles que lhes praticam. Todos esses elementos contribuem significativamente para o estabelecimento de um tipo de gestão e organização do trabalho que conduz à individualização do trabalhador, haja vista que "as firmas exigem do trabalhador uma profunda interação com os objetivos da empresa e, para tanto, inúmeras medidas são implementadas em um contexto de controle, tensões e solicitações. O apelo à subjetividade do trabalhador é uma constante desses novos modelos, investindo na motivação e no desenvolvimento da qualidade pessoal de cada um" (LINHART, 2000, p. 27).

No entanto, é preciso considerar que esse processo de mudança na subjetividade dos trabalhadores não os torna meros expectadores passivos, e aqui consideramos necessário levar em consideração aquilo que Giddens (1991; 1997; 2002) denomina de reflexividade, isto é, a capacidade de cognição que os atores sociais possuem a respeito do modo como suas ações têm impacto sobre o mundo e como este o tem sobre eles. Nessa linha interpretativa, os indivíduos são entendidos como atores sociais, agentes humanos, sujeitos providos de uma capacidade de cognição que lhes permite um considerável conhecimento das condições e consequências do que fazem em suas vidas cotidianas. Nesses termos, isso implica em um ponto de partida hermenêutico, porque para compreendermos as atividades humanas no âmbito de determinada sociedade, devemos proceder ao exame do conhecimento que os próprios atores sociais têm de suas condutas. Por isso, para Giddens, existiriam dois níveis de análise na compreensão da conduta reflexiva: em primeiro plano, a reflexividade está contida na consciência discursiva dos atores sociais e, em um segundo plano, a reflexividade está contida na consciência prática dos atores sociais.

As técnicas de gestão inspiradas no modelo japonês, além de intensificarem o processo de trabalho, ainda trazem consigo a estratégia de sub- 
meter ao máximo o trabalhador à égide dos interesses das empresas. Os discursos empresariais atuais enfatizam que a parceria entre o capital e o trabalho é capaz de gerar mais benefícios do que malefícios para os trabalhadores. Tal crença tenta adquirir consistência e legitimidade a partir de um aparato discursivo-ideológico no qual o trabalhador, no contexto da fábrica, deve perceber-se como valorizado em sua autonomia para tomar decisões sobre o processo de trabalho ao qual está sujeito, mesmo que tal autonomia seja apenas relativa, já que se depara com os norteamentos que estão implícitos nas estratégias adotadas pela alta administração das empresas. Nesse sentido, autores como Antunes defendem que "a subsunção do ideário do trabalhador àquele veiculado pelo capital, a sujeição do ser que trabalha ao 'espírito' Toyota, à 'família' Toyota, é de muito maior intensidade, é qualitativamente distinta daquela existente na era do fordismo. Esta era movida centralmente por uma lógica mais despótica; aquela, a do toyotismo, é mais consensual, mais envolvente, mais participativa, em verdade mais manipulatória" (ANTUNES, 2005, p. 42; grifos no original).

Para Antunes, as empresas que se inspiram no modelo japonês promovem um "envolvimento cooptado" que permite a apropriação do saber e do fazer dos trabalhadores, fazendo-os pensar e agir em consonância com os interesses do capital, isto é, visando o aumento da produtividade. No rastro dessa mesma linha interpretativa, Alves (1999) advoga que o toyotismo não deve ser considerado um novo modo de regulação da economia capitalista, tal como o fordismo fora identificado pelos integrantes da chamada escola da regulação, mas sim como uma nova lógica de produção de mercadorias, um novo conjunto de princípios de administração da produção capitalista e de gestão da força de trabalho, no qual o intento fundamental é constituição de uma nova hegemonia do capital na produção. Até este ponto não temos o que discordar dessa linha interpretativa, porém não compartilhamos da idéia, mais especificamente do segundo autor, de que essa nova hegemonia processe-se por intermédio da "captura da subjetividade" operária.

Falar em "envolvimento cooptado" soa-nos pertinente e heuristicamente válido, desde que se entenda haver certa margem de liberdade na ação de envolver-se. Por sua vez, falar em "captura da subjetividade" soa-nos mais como uma categoria dotada de conteúdo retórico do que propriamente analítico, não porque não haja uma ofensiva do capital sobre a subjetividade dos trabalhadores, mas sim porque falar em captura remete a arresto, a apreensão, a aprisionamento, o que pressupõe ausência de liberdade, como se a subjetividade de alguém estivesse única e exclusivamente circunscrita nos limites de sua identidade como membro da classe trabalhadora.

Para nós, mais ofensivo do que a ofensiva do capital é pensar que as adesões dos que se permitem "iludir" são simples evidências de uma condição de alienação e estranhamento alimentada por discursos ideológicos que lhes destituem a capacidade de cognição da realidade, isto é, de sua condição de reflexividade sobre o modo como o mundo social afeta-lhes e por eles é afetado; capacidade esta que é inerente a todos, mas que se manifesta de formas e em níveis diferenciados, de acordo com as distribuições de capital econômico em suas diferentes formas, de capital cultural e de capital simbólico que estão em jogo tanto nas relações objetivas, quanto nas relações subjetivas existentes entre os agentes sociais (BOURDIEU, 2004).

A operação de redefinição da condição de trabalhador para "colaborador interno" ou "cliente interno" está claramente inscrita no conjunto de estratégias que objetiva transformar a subjetividade do trabalhador no que diz respeito ao modo como ele percebe sua relação com a empresa, ou se preferirmos, a relação capital-trabalho. No entanto, para essa ressignificação parecer minimamente verossímil aos olhos dos trabalhadores; ela precisa sair da simples esfera discursiva e passar a ser vivenciada no espaço fabril em que o processo de trabalho ocorre, caso contrário, o sentido do envolvimento que se busca obter fica comprometido, já que seu conteúdo simbólico esvaise na experiência das práticas cotidianas e, conseqüentemente, a opacidade da situação seria sentida na discrepância entre o que versam as prescrições discursivas gerenciais e o que efetivamente operacionalizam as práticas gerenciais.

Tendo isso em mente, entendemos ser fundamental considerar que a lógica da flexibilização produtiva não apenas desmobiliza o coletivo de trabalhadores pela via da fragmentação de classe promovida pelas novas formas de contrato de trabalho, ela também produz aquilo que Zarifian cha- 
ma de um engajamento subjetivo, isto é, uma situação que se apresenta como possuidora de duas faces, quais sejam: "a da captação da atividade subjetiva do assalariado, sob uma forma renovada de relação de dominação, e a do sentido pessoal e coletivo dado à ação social, sob uma forma renovada de relação de emancipação" (ZARIFIAN, 2002, p. 30). Para Zarifian, e aqui alinhamo-nos ao seu modo de ver, qualquer análise que tente isolar uma face da outra está fadada à não compreensão dessa realidade.

A manifestação do engajamento subjetivo dos trabalhadores nos modelos de organização de trabalho inspirados na lógica da flexibilização se manifesta por meio de um "assujeitamento consentido", pois mesmo o envolvimento sendo forçado, "no sentido de uma força que se exerce sobre a força do assalariado de maneira estruturalmente desigual" (idem, p. 31), não é possível falar em ausência de liberdade. Até mesmo porque, como ressalta Zarifian: “[...] há a liberdade. E liberdade, em primeiro lugar, no exercício da potência de pensar, agir e cooperar dos indivíduos-sujeitos (que se tornam sujeitos nesse exercício). Todas as pesquisas que realizo, há mais seis anos, em grandes empresas de serviços me confirmam esta asserção: não somente os sujeitos demandam iniciativas, mas as exercem. O que há de novo é que a sociedade de controle, num movimento paradoxal, por deslegitimar e fluidificar a disciplina taylorista, amplia e mistura os devires em que se engajam os sujeitos: o devir não mais se limita à empresa que os emprega, combinando-se, muito mais diretamente que antes, com a pluralidade de devires, precisamente porque os espaços (a família, a escola, a fábrica, o hospital etc.) deixam de ser fechados e, por conseguinte, os problemas que supostamente deveriam regrar (ordenar) deixam de ser confinados e estritamente delimitados" (ibidem).

A "adesão" dos trabalhadores à lógica da flexibilização produtiva que passa a nortear a organização do trabalho dentro das empresas parece ocorrer com uma abdicação relativamente consciente de um possível projeto de classe, mas não com a abdicação de um busca por emancipação do indivíduo. Aos olhos daqueles que possuem uma visão monolítica da relação capital-trabalho, se essa situação parece claramente caracterizar uma sujeição ideológica a um projeto que não seja o mais adequado aos "interesses" (seus) da clas- se trabalhadora, para os trabalhadores, no nível de suas vivências práticas, confere-lhes a sensação de fazer-se parte de uma coletividade que oportuniza, mesmo que de modo instável e transitório, a sensação de transcender o mero pertencimento amorfo da condição de classe.

Isso porque, devido às diversas nuanças da realidade e às diversas formas de percebê-la, principalmente no nível das vivências cotidianas dos trabalhadores afetados pelas estratégias de produção de assujeitamento consentido, é preciso considerar que em uma sociedade de indivíduos, coisa que o são todas as sociedades minimamente inscritas no legado do projeto iluminista da modernidade, para o bem ou para o mal, "lado a lado com o desejo de ser alguém por si, ao qual a sociedade dos outros se opõe como algo externo e obstrutivo, freqüentemente existe o desejo de estar inteiramente inserido na sociedade. A necessidade de se destacar caminha de mãos dadas com a necessidade de fazer parte. O sentimento de participar, de estar envolvido, muitas vezes se mistura com o de estar descomprometido, desligado - 'Que me importa tudo isto?' [...] o objetivo de ser alguém único e incomparável é acompanhado, muitas vezes, pelo de não se destacar, de se conformar" (ELIAS, 1994, p. 124).

Se, por um lado, o "engajamento subjetivo" produzido pela lógica da flexibilização produtiva faz os trabalhadores submeterem-se ao ideário do capital quando da introjeção dos valores da cultura organizacional e da sensação de fazer parte da "grande família" que ela pretende ideologicamente representar, por outro, concretamente dá-lhes um sentimento de pertença a uma coletividade, sentimento este que é efetivamente sentido nas suas vivências cotidianas, por mais instável e transitório que isso possa vir a ser e por mais tensões que possam existir entre os trabalhadores e a empresa. De um modo geral, essa situação cria um cenário no qual a ideia de maior responsabilização no processo produtivo pode ser assimilada de forma relativamente positiva por um grande contingente de trabalhadores.

Entretanto, não podemos esquecer a existência de um elemento crucial de desmobilização coletiva que é inerente ao projeto de globalização de inspiração neoliberal: a percepção de que o Estado é uma instância incapaz de assumir o protagonismo na tarefa de promover o bom funcionamento da sociedade como um todo. Mais isto: que tal situa- 
ção corresponde muito mais a uma construção discursiva que lhe imputa essa condição do que propriamente às impossibilidades que lhes sejam inerentes.

Como lembra-nos Bourdieu (2002), esse discurso não possui a neutralidade alegada por seus defensores, até porque sua origem é socialmente bem definida e sustenta-se em três postulados distorcidos da teoria econômica: 1) a economia entendida como um domínio à parte do mundo social, esfera regida por leis naturais e universais que não podem ser contrariadas pelos governos; 2) o mercado como sendo a instância capaz de otimizar a organização das relações sociais, as trocas, a produção, assim como garantir uma distribuição equitativa; 3 ) a exigência pela redução das despesas do Estado no âmbito de uma economia globalizada, ou seja, a supressão de tudo que possa vir a ser um impeditivo para a expansão dos mercados, e aqui estão incluídos os direitos sociais ligados ao emprego e à previdência social, vistos nessa linha de raciocínio, que resgata a lógica do laissez faire, como onerosos e disfuncionais. Aliado a essas distorções, ainda se têm o discurso, nitidamente inspirado no velho discurso americano calvinista do self-help ('virar-se' por conta própria). Ante a situação configurada por essa lógica discursiva, não é de se estranhar que "nesse momento, no mundo inteiro só se fala em responsabilidade. Evidentemente o axioma principal é que o pobre é responsável por sua pobreza. Em meu jargão, digo que isso é uma sociodicéia, ou seja, uma narrativa que tem por função justificar a sociedade tal como ela é" (BOURDIEU, 2002, p. 26; grifos no original).

A incorporação dessa narrativa conduz os indivíduos à crença de que a transformação de suas condições de vida é uma tarefa que compete exclusivamente a si mesmos, de modo isolado ou agregado a outros indivíduos que estejam em situações semelhantes (vide, por exemplo, o crescimento das cooperativas de trabalho e de produção no Brasil a partir do final dos anos de 1980, situação demonstrada nos trabalhos de Lima (2002; 2004).

Como aponta Castel (2005), o discurso da responsabilização dos agentes na era da flexibilização produtiva está inegavelmente associado ao processo de individualização das tarefas e das trajetórias profissionais decorrentes das reestruturações ocorridas no mundo do trabalho.
A promoção dessas reestruturações sustenta-se em um discurso disseminado pelo mundo empresarial de que se faz necessário maximizar o desempenho das empresas visando torná-las competitivas ante os desafios impostos pelo ambiente de concorrência exacerbada que caracterizam os enredamentos de uma economia capitalista globalizada.

Nessa linha discursiva de responsabilização dos agentes, o problema maior não vem a ser como o atual estágio de acumulação capitalista configurase, mas sim como disseminar o espírito empreendedor para aqueles sobre os quais a destituição do acesso a um emprego socialmente protegido impõe-se. Alicerçada em uma ideologia da competência, essa narrativa produz o cenário propício à disseminação da idéia do indivíduo como empreendedor de si mesmo, isto é, responsável por sua condição de empregabilidade. Como lembra-nos Freitas, é inerente a essa lógica a idéia de que "se cada um é o projeto de si mesmo, quem não consegue emprego é porque não soube escolher as qualificações que as empresas necessitam ou podem vir a necessitar" (FREITAS, 2006, p. 77).

Desse modo, o precário naturaliza-se na esfera do trabalho à medida que esse discurso é assimilado pelos trabalhadores como a resposta mais adequada para o desemprego estrutural que se apresenta como condição inerente ao atual estágio de configuração da economia capitalista. Em decorrência disso, o trabalhador, dentro e fora do ambiente fabril, cada vez mais se percebe como o único responsável por si mesmo, mesmo que o desemprego ameace-lhe não apenas no sentido de tomar-lhe o trabalho como meio de sustento de vida, mas acima de tudo, como meio de conferir sentido a ela.

No atual estágio de acumulação capitalista, temos uma situação em que as constantes inovações tecnológicas espraiam-se em escala global de maneira isomórfica e a lógica da flexibilização tornou-se, ao mesmo tempo, norteadora das diretrizes organizacionais do mundo empresarial e força debilitadora dos direitos sociais ligados às conquistas dos movimentos de trabalhadores no decorrer do século XX. Como consequência, os indivíduos que ingressam hoje no mercado de trabalho são impelidos a desenvolver uma capacidade quase que "reflexa" de adaptação ante as mudanças técnico-organizacionais ocorridas no mundo do trabalho e de recuperação ante os "infortú- 
nios" que sobre eles possam vir a abater-se, como por exemplo, uma demissão decorrente de um processo de enxugamento no quadro funcional ou uma redução no elenco de benefícios oferecidos pelas empresas. Desse modo, a capacidade de resiliência torna-se um dos elementos que compõem o perfil do trabalhador almejado pelas empresas em tempos de produção flexível. Entendamos por resiliência não uma atitude resignada ante as desventuras vividas no mundo social, e em nosso caso, mais especificamente no mundo do trabalho, mas sim, aquilo que Grotberg designa como, "a capacidade humana para enfrentar, vencer e ser fortalecido ou transformado por experiências de adversidade. [...] As condutas resilientes supõem a presença e a interação dinâmica de fatores e esses fatores vão mudando nas diferentes etapas do desenvolvimento. As situações de adversidade não são estáticas, mudam e requerem mudanças nas condutas resilientes. A conduta resiliente exige se preparar, viver e aprender com as experiências adversas (GROTBERG, 2005, p. 15-17).

No mundo do trabalho, isso não é visível apenas a partir das necessidades que os trabalhadores passam a ter de adaptarem-se e de superar rapidamente as inovações técnico-organizacionais impostas pela lógica da flexibilização produtiva, que lhes exige um nível mais elevado de responsabilização no processo produtivo e um maior envolvimento com a cultura organizacional da empresa. Mas também o é quando consideramos a disseminação do discurso de responsabilização dos indivíduos pela sua condição de empregabilidade, discurso que se personifica na figura do empreendedor de si mesmo. As veiculações hodiernas desses discursos não objetivam apenas a tentativa de constituir um novo tipo de trabalhador, mas acima de tudo um novo tipo humano; um tipo mais afeito e adequado aos riscos característicos de uma economia global sujeita às instabilidades dos mercados financeiros e à insegurança social e ontológica provenientes de uma situação de precarização de direitos sociais vinculadas à condição de assalariamento e de uma redução ao status de cidadania quase que exclusivamente à capacidade de tornarem-se consumidores.

Assim, torna-se extremamente difícil, para parte considerável dos indivíduos, a percepção de si mesmo como sujeito plenamente seguro de suas vinculações sociais e do papel que lhe poderia caber na esfera pública; o que não significa dizer que não exista margem alguma para a reflexão dos indivíduos sobre o modo como se inserem e como atuam no mundo social. Contudo, não podemos perder de vista que as dificuldades produzidas por essa situação acabam convertendo indivíduos que poderiam potencialmente desenvolverse como sujeitos efetivamente autônomos dentro do mundo do trabalho em objetos sobre os quais incidem os efeitos deletérios da ação de mercados cada vez mais fluídos, voláteis e instáveis.

Por isso, o que se tem é algo muito próximo de uma massa amorfa incapaz de conceber e construir qualquer projeto de interesse comum, já que a única coisa que compartilham é uma condição comum de incapacidade de integração, como muito bem mostrou Hannah Arendt $(1989 ; 2005)$ em seus estudos sobre os regimes totalitários, e, mais recentemente, tem-nos mostrado Robert Castel $(2003 ; 2005)$, quando fala de uma situação de desassociação social decorrente do desmantelamento do que ele chama de projeto de sociedade salarial; situação esta que caracteriza o processo de desfiliação dos indivíduos ante a coletividade, pois como defende Castel, o trabalho deve ser pensando não "enquanto relação técnica, mas como suporte privilegiado de inscrição na estrutural social" (CASTEL, 2005, p. 24), não o único suporte, mas um suporte privilegiado, pois é preciso reconhecer que há "uma forte correlação entre o lugar ocupado na divisão social do trabalho e a participação nas redes de sociabilidade de proteção que 'cobrem' um indivíduo diante dos acasos da existência. Donde há a possibilidade de construir o que chamarei, metaforicamente, de 'zonas' de coesão social. Assim, a associação trabalho estável - inserção relacional sólida caracteriza uma área de integração. Inversamente a ausência de participação em qualquer atividade produtiva e o isolamento relacional conjugam seus efeitos negativos para produzir a exclusão, ou melhor, [...] a desfiliação. A vulnerabilidade social é uma zona intermediária instável, que conjuga a precariedade do trabalho e a fragilidade dos suportes de proximidade" (ibidem).

Para nós, está claro que, apesar de não estarmos mais diante de problemas produzidos pelos estados totalitários analisados por Arendt, estamos diante dos efeitos produzidos por aquilo que Oliveira (1999) chama de totalitarismo neoliberal, no 
qual as sensações de insegurança social e ontológica são nutridas pelas estratégias de desmantelamento do Estado como esfera pública e pelas estratégias de flexibilização tanto interna quanto externa no mundo empresarial.

A instabilidade e o desprovimento de uma rede de proteção social que caracterizam as situações dos que são afetados por essa situação de desassociação social contribui significativamente para uma sensação de incerteza do presente, sensação essa que, como nos chama atenção Bauman, "age como uma poderosa força individualizadora" (BAUMAN, 2001, p. 170), pois conduz a uma impossibilidade de planejar o futuro na esfera privada e a uma obstacularização da possibilidade de pensar-se a idéia de interesses comuns. Desta feita, a possibilidade de construção de vínculos coletivos duradouros vê-se cada vez mais debilitada. Até mesmo por que "os medos, ansiedades e angústias contemporâneos são feitos para serem sofridos em solidão. Não se somam, não se acumulam numa 'causa comum', não têm 'domicilio natural'. Isso destitui uma postura solidária que teve lugar no passado como tática racional e indica uma estratégia de vida totalmente diferente da que conduziu ao estabelecimento da defesa da classe trabalhadora e de suas organizações militantes (idem, p. 35).

Como indica Sennett, não é à toa que, "no regime flexível, as dificuldades cristalizam-se num determinado ato, o ato de correr riscos" (SENNETT, 2005, p. 88). Se o herói do capitalismo flexível é o indivíduo destinado a correr risco e a "pagar para ver" independente de ser o resultado recompensador ou não, não podemos esquecer que a incorporação do desígnio da incerteza conduz a uma impossibilidade de planejar o futuro na esfera privada e a obstacularização do pensar a idéia de interesses comuns na esfera pública.

\section{CONCLUSÕES}

Apesar de considerarmos pertinente a hipótese da constituição de um novo trabalhador coletivo pela flexibilização produtiva, quando do estabelecimento de um modelo de cooperação baseado nos princípios da responsabilidade, qualificação e participação, acreditamos que o elemento potencialmente de maior ruptura com o período fordista é a constituição de um novo indivíduo. Novo indivíduo que possui basicamente três ca- racterísticas: 1) desfiliação dos laços coletivos de pertencimento à classe social; 2) responsabilização por sua condição de empregabilidade; 3 ) capacidade de resiliência como fonte de renovação de suas energias ante aos reveses sofridos não apenas no mundo do trabalho.

Diante dessas constatações, defendemos que o processo de individualização produzido pela situação de desassociação social configura-se como potencialmente deletério, porque atira os indivíduos a uma condição de "virar-se" e agir por conta própria, a uma condição de guerra de todos contra todos - no melhor sentido hobbesiano do termo -, instaurada por um luta pela sobrevivência claramente inspirada em um darwinismo social que fornece suporte ideológico para a gradativa desregulação do mercado trabalho. Assim, uma eventual potencialidade positiva do processo de individualização não se realiza, pois as sociedades capitalistas contemporâneas estão assentadas sobre a égide da volatilidade e do descomprometimento do capital financeiro em relação a quaisquer demandas sociais que ponham em risco seu círculo reprodutivo. Cindida por relações sociais fluídas e transitórias e sem poder contar mais com o suporte de trajetórias profissionais mais seguras e lineares, a sociedade dos indivíduos em tempos de flexibilização e precarização testemunha a insuficiência da experiência do reconhecimento social nas esferas de sociabilidade meramente instrumentais.

Em um cenário global de crescente desassociação e exclusão social, produzidas pela hegemonia do capital financeiro, fica difícil falar em coletividades de indivíduos. O que parece restar são coleções de indivíduos, visto que cada vez mais estes são lançados à própria sorte, chamados à responsabilização pela permanência ou não em determinada condição de existência material e apenas circunstancialmente percebendo-se como inseridos em algum tipo de coletividade - porque delas sentem-se desfiliados -, a qual, no caso do mundo do trabalho, corresponderia à responsabilização pela condição de empregabilidade.

Em um mundo em que a condição de precariedade tende a naturalizar-se, o discurso da responsabilização individual, revigorado e com ares de desprendimento diante de filiações coletivas como Estado-nação, classe ou, até mesmo, a família, entendidas nessa matriz como âncoras que impedem o indivíduo de realizar toda a sua 
potencialidade, não soa necessariamente como falacioso, mas tão pouco soa como verdadeiro. Para espraiar-se basta-lhe soar minimamente verossímil.

Tal discurso localiza-se em uma zona cinzenta, na qual é processada uma redefinição cognitiva das funções do Estado, dos mercados e principalmente da noção de indivíduo, uma zona nebulosa em que o trabalho perde espaço para a empresa como referencial de mundo, não por ser esta o lugar da acumulação de capital ou o lugar onde ganha-se o sustento ou é possível dignificar-se com o trabalho, mas por ser o lugar onde empreende-se, onde incentiva-se a disposição de aprendizado constante, que estimula o estar aberto para viver coisas novas e desprender-se das antigas, $o$ lugar onde a racionalidade instrumental coloniza a subjetividade do indivíduo e canaliza-a para o exercício da ação de voltar-se para si mesmo.

No nível dos discursos e das narrativas, o que estamos testemunhando é uma tentativa de construção da imagem do empreendedor de si mesmo como o indivíduo capaz de vencer as incertezas e inseguranças da vida social dentro do contexto do capitalismo flexível. Por outro lado, no nível das vivências práticas, o que de fato estamos testemunhando é muito mais o alargamento das fileiras das vítimas dos efeitos deletérios da flexibilização produtiva.

Em outras palavras, estamos diante de um indivíduo jogado em um mundo em que uma forma de sociabilidade baseada na condição de precariedade tende a naturalizar-se. Para tal, os discursos de inspiração neoliberal tentam realçar tão somente a dimensão positiva da figura do empreendedor de si mesmo e gradativamente esvaziar o caráter nocivo que as noções de incerteza e insegurança possuem no imaginário dos que nunca vivenciaram, e que, até segunda ordem, não mais terão a possibilidade de vivenciar alguns importantes direitos sociais ligados ao mundo do trabalho.

Attila Magno e Silva Barbosa (barbosaattila@hotmail.com) é Doutor em Sociologia pela Universidade Federal de São Carlos (Ufscar).
Todavia, não podemos esquecer que esses discursos não fazem os efeitos deletérios da condição de precariedade desaparecerem da vida dos desfiliados e dos que não mais poderão filiar-se, apenas os escamoteiam insidiosamente no discurso de responsabilização individual, apenas fazem crer que os lugares ocupados pelos indivíduos na estrutura social ou são uma decorrência do simples mérito de cada um ou da simples falta dele, ou, o que é pior ainda, uma mera questão de ter ou não "o perfil desejado pelo mercado".

Portanto, estamos diante de um indivíduo muito mais desvinculado de qualquer sentido de pertença coletiva e desprovido de qualquer sentido do que venha a significar o termo proteção social do que de um indivíduo efetivamente capaz de converter-se em senhor de si mesmo, no âmbito de uma sociedade que se pretende igualitária. Até mesmo porque, quando consideramos a experiência da precariedade profissional que se instaura no mundo da flexibilização produtiva e afeta um número cada vez maior de pessoas, como defende Paugam (1999), a desqualificação social produzida por essa situação é nitidamente uma experiência humilhante e desestabilizadora das relações com os outros, tendendo, assim, a fragilizar os vínculos sociais e a conduzir o indivíduo a fechar-se sobre si mesmo.

Se tal idéia de indivíduo soa como dotada de sentido e tem certa força como paradigma de comportamento para muitos, mesmo que esses muitos não possuam condições socioeconômicas favoráveis para pô-la em prática, é porque ela parece estar em estreita consonância com os tipos de relações sociais que são configuradas pela lógica da flexibilização produtiva. Porém, é preciso lembrar, como o faz Castells, que "as elites são cosmopolitas, as pessoas são locais. Os espaços de poder e riqueza são projetados pelo mundo, enquanto a vida e a experiência das pessoas ficam enraizadas em lugares, em sua cultura, em sua história" (CASTELLS, 2002, p. 505). 


\section{REFERÊNCIAS BIBLIOGRÁFICAS}

ALVES, G. 1999. Trabalho e mundialização do capital: a nova degradação do trabalho na era da globalização. Londrina: Práxis.

ANTUNES, R. 1999. Os sentidos do trabalho: ensaio sobre a afirmação e a negação do traba1ho. São Paulo: Boitempo.

2005. Adeus ao trabalho? $10^{\mathrm{a}}$ ed. São Paulo: Cortez.

ARENDT, H. 1989. Origens do totalitarismo. São Paulo: Companhia das Letras.

2005. A condição humana. $10^{\mathrm{a}} \mathrm{ed}$. Rio de Janeiro: Forense.

BARBOSA, A. M. S. 2007. Cidadania empresarial: o ardil da destituição do dissenso. Ciências Sociais Unisinos, São Leopoldo, v. 43, n. 3, p. 267-276, set.-dez. Disponível em: http:// redalyc.uaemex.mx/pdf/938/93843309.pdf. Acesso em: 21.dez.2010.

BAUMAN, Z. 1998. Work, Consumerism and New Poor. Buckingham: Open University.

2001. La sociedad individualizada. Madrid: Catedra.

2003. Comunidade: a busca por segurança no mundo atual. Rio de Janeiro: J. Zahar.

2005. Identidade: entrevista com Benedetto Vecchi. Rio de Janeiro: J. Zahar.

BENSASSOLI, P. F. 2007. Trabalho e identidade em tempos sombrios. Aparecida: Idéias \& Letras.

BIHR, A. 1998. Da grande noite à alternativa: o movimento operário europeu em crise. $2^{\mathrm{a}}$ ed. São Paulo: Boitempo.

BOURDIEU, P. 1998. O poder simbólico. Rio de janeiro: Bertrand Brasil.

2002. Pierre Bourdieu entrevistado por Maria Andréa Loyola. Rio de Janeiro: UERJ.

In:

2004. Espaço social e poder simbólico. In: . Coisas ditas. São Paulo: Brasiliense.

CASTEL, R. 2003. As metamorfoses da questão social: uma crônica do salário. $4^{\mathrm{a}}$ ed. Petrópolis: Vozes.
2005. A insegurança social: o que é ser protegido? Petrópolis: Vozes.

CASTELLS, M. 2002. A sociedade em rede. V. I: - A era da informação: economia, sociedade e cultura. $6^{\text {a }}$ ed. São Paulo: Paz e Terra.

CORIAT, B. 1994. Pensar pelo avesso: o modelo japonês de trabalho e organização. Rio de Janeiro: UFRJ.

CHOMSKY, N. 2002. Olucro ou as pessoas? Rio de Janeiro: Bertrand Brasil.

DiMAGgio, P. \& POWELL, W. 1999. Retorno a la jaula de hierro: el isomorfismo institucional y la racionalidad colectiva en los campos organizacionales. In: P. DIMAGGIO, P. \& POWELL, W. (orgs.). El nuevo institucionalismo en el análisis organizacional. México: Fondo de Cultura Econômica.

DUPAS, G. 1999. Economia global e exclusão social. $2^{\mathrm{a}}$ ed. São Paulo: Paz e Terra.

ELIAS, N. 1994. A sociedade dos indivíduos. Rio de Janeiro: J. Zahar.

EHRENBERG, A. 1991. Le culte de la performance. Paris: Calmann-Lévy. Lévy.

. 1995. L'individu incertain. Paris: Calmann-

FREITAS, M. E. 2006. Cultura organizacional: identidade, sedução e carisma? $5^{\text {a } e d . ~ S a ̃ o ~ P a u-~}$ lo: Fundação Getúlio Vargas.

GIDDENS, A. 1991. As conseqüências da modernidade. São Paulo: UNESP.

1997. A vida em uma sociedade pós-tradicional. In: GIDDENS, A.; BECK, U. \& LASCH, S. Modernidade reflexiva. São Paulo: UNESP.

.2002. Modernidade e identidade. Rio de Janeiro: J. Zahar.

GORZ, A. 1987. Adeus ao proletariado. Rio de Janeiro: Forense.

GROTBERG, E. 2005. Introdução: novas tendências em resiliência. In: MELILLO, A. \& OJEDA, E. N. S. (orgs.). Resiliência: descobrindo as próprias fortalezas. Porto Alegre: Artmed. 
HABERMAS, J. 1990. A nova intransparência. A crise do Estado de Bem-Estar Social e o esgotamento das energias utópicas. Novos Estudos, São Paulo, n. 18, p. 103-114, set. Disponível em: http://www.scribd.com/doc/ 33883796/A-Nova-intransparencia-Habermas. Acesso em: 21.dez.2010.

HARVEY, D. 2004. Condição pós-moderna. $13^{\mathrm{a}}$ ed. São Paulo: Loyola.

LIMA, J. C. 2002. As artimanhas da flexibilização: o trabalho terceirizado em cooperativas de produção.

2004. O trabalho autogestionário em cooperativas de produção: o paradigma revisitado. Revista Brasileira de Ciências Sociais, São Paulo, v. 19, n. 56, p. 45-62. Disponível em: http://www.scielo.br/pdf/rbcsoc/v19n56/ a04v1956.pdf. Acesso em: 22.dez.2010.

LINHART, D. 2000. O indivíduo no centro da modernização das empresas: um reconhecimento esperado, mas perigoso. Revista Trabalho e Educação, Belo Horizonte, n. 7, p. 2436, jul.-dez.

MARX, K. 2008. O capital. V. 1. Rio de janeiro: Civilização Brasileira.

NARDI, H. 2006. Ética, trabalho e subjetividade. Porto Alegre: UFRGS.

NEVES, M. A. 2006. As novas configurações do trabalho: diversidade, precarização e dominação. In: PORTO, M. S. G. \& DWYER, T. (orgs.). Sociologia em transformação: pesquisa social do século XXI. Porto Alegre: Tomo.
OFFE, C. 1989. Trabalho como categoria fundamental. In: OFFE, C. (org.). Capitalismo desorganizado: transformações contemporâneas do trabalho e da política. São Paulo: Brasiliense.

OHNO, T. 1997. O sistema Toyota de produção: além da produção em larga escala. São Paulo: Bookman.

OLIVEIRA, F. 1999. Privatização do público, destituição da fala e anulação da política: o totalitarismo neoliberal. In: OLIVEIRA, F. \& PAOLI, M. C. (orgs.). Os sentidos da democracia: políticas do dissenso e hegemonia global. Petrópolis: Vozes.

PAOLI, M. C. 2002. Empresas e responsabilidade social: os enredamentos da cidadania no Brasil. In: SANTOS, B. S. (org.). Democratizar a democracia: os caminhos da democracia participativa. Rio de Janeiro: Civilização Brasileira.

PAUGAM, S. 1999. O enfraquecimento e a ruptura dos vínculos sociais: uma dimensão essencial do processo de desqualificação social. In: SAWAIA, B. (org.). As artimanhas da exclusão: análise psicossocial e ética da desigualdade social. $8^{\mathrm{a}}$ ed. Petrópolis: Vozes.

SENNETT, R. 2005. A corrosão do caráter: conseqüências pessoais do trabalho no novo capitalismo. Rio de Janeiro: Record.

TIDDI, A. 2002. Percorsi di vita tra lavoro e non lavoro. Roma: Derive Approdi.

ZARIFIAN, P. 2002. Engajamento subjetivo, disciplina e controle. Novos Estudos, São Paulo, n. 64, p. 23-31, nov. 


\section{BEING ONE'S OWN ENTREPRENEUR AND FLEXIBILIZATION IN THE WORLD OF WORK}

\section{Attila Magno e Silva Barbosa}

The social existence of individuals, for many of their interpreters - whether the latter resort to religious or political discourses or even certain currents of sociological thought - seems not to be possible without the existence of metanarratives that infuse it with meaning. This article engages in theoretical discussion of the discursive construction of those who act as their own entrepreneurs, as individuals capable of confronting quick and drastic changes occurring within the world of work with the advent of productive flexibilization. We advocate the hypothesis that this discursive construction does not portray a type of individual that is potentially accessible to all, insofar as it refers to a construction that does not involve the support of a shared societal project. In other words, we are looking at a type of individual who is disconnected from social ties and lacking in any type of State- supplied social protection and therefore, cannot provide a universal standard of behavior for a society that seeks to attenuate social inequality.

KEYWORDS: Flexible Production; Precarization; Social and Ontological Insecurity; Entrepreneurship. 


\section{L'ENTREPRENEUR DE SOI ET LA FLEXIBILISATION DANS LE MONDE DU TRAVAIL} Attila Magno e Silva Barbosa

L'existence sociale des individus, pour beaucoup de ses interprètes, soit par la voie de discours religieux, de discours politiques ou soit même par la voie de certains courants de la pensée sociologique, semble ne pas être possible sans l'existence de métarécits pour les donner du sens. Cet article vise faire une discussion théorique sur la construction discursive de l'entrepreneur de soi tant qu'un individu capable de faire face aux changements rapides et radicaux qui ont lieu dans le monde du travail avec l'avènement de la flexibilisation productive. Nous défendons l'hypothèse que cette construction discursive ne présente pas un type d'individu potentiellement accessible à tous, car il présuppose la construction de soi sans les appuis d'un projet commun de société. En d'autres termes, nous sommes devant un type d'individu séparé des domaines collectifs et sans aucun type de protection sociale fournie par l'Etat et, pour ça, sans possibilité d'être considéré comme un standard universel de comportement dans une société qui cherche la diminution des inégalités sociales.

MOTS-CLES: production flexible; précarisation; insecurité sociale et ontologique; entrepreneur de soi. 